\title{
Tinédzserek titkos kapcsolata az internettel
}

Kaveri Subrahmanyam - David Smahel (2011): Digital Youth -The role of media in development c. könyve

Így hivatkozzon erre a cikkre:

Dóra László. „Tinédzserek titkos kapcsolata az internettel”.

A folyóiratban közölt müvek a Creative Commons Nevezd meg! - Ne add el! - Így add tovább! 4.0

Nemzetközi Licenc feltételeinek megfelelően használhatók. 


\title{
Dóra László
}

\section{Tinédzserek titkos kapcsolata az internettel}

\author{
A Digital Youth ${ }^{1}$ címú könyv recenziója
}

A fiatalok és a digitális világ kapcsolatát bemutató 2014-es kiadvány egy jól felépített tudományos könyv. Sokszínúsége érték, nem csak az egyoldalú pszichológiai megközelítést képviseli a témával kapcsolatban, hanem nagyon sok nemzetközi kutatásra is felhívja a figyelmet. A szerzôpáros egyik tagja az Egyesült Államokban dolgozik, a másik pedig Európában, Csehországban. Mindketten az újmédia és lélektan kapcsolatának szakértói, és nagyon jól kiegészítik egymást a tengerentúli és európai felfogást képviselve.

A könyv bevezetó fejezete általános áttekintést ad a média és a fiatalok kapcsolatáról, és grafikonokkal, táblázatokkal szemlélteti a fontosabb adatokat. A könyv érdekessége, hogy magyarországi adatokat is találunk benne. A 2007-es World Internet Project adatait használva kiemeli, hogy nyolc éve Magyarországon a televíziózás vezette a listát a digitális eszközök használatában. Egy másik ábrán az amerikai és kanadai kamaszok internet használati szokásait szemlélteti. A kutatás széleskörú volt, ezt jól mutatja a humoros oldalak felkeresésére vonatkozó kérdés, vagy a szavak jelentésére való rákeresés. A leggyakoribb természetesen az üzenetküldés, e-mailezés, a „csak úgy” böngészés, illetve ezt követi a zenehallgatás vagy letöltés, és az on-line játékok vagyis a szórakozás. Ez a bevezetó fejezet több kis részból áll, és inkább csak elốrevetíti, megalapozza a kiadvány további részeit. A fejezet utolsó része a könyv szerkezeti felépítését és a hozzá rendelt tartalmakat mutatja hozzávetólegesen egy oldalon. Itt lehet megérteni azt a logikai gondolatmenetet, amire az egyes fejezetek épülnek. Külön érdeme a könyvnek, hogy minden egyes fő egység után megtalálható a szakirodalom jegyzék, amely így megkönnyíti a tájékozódást az egyes résztémákban.

A második fejezet az egész könyv koncepcióját és látásmódját taglalja. A fejlôdéspszichológiai nézópontot a középpontba állító megközelítés, a könyv egészében hangsúlyos, de nagyon helytálló. Ez a kutatási irány mindig is fontos volt, és fontos is lesz a gyerekekkel foglalkozók körében, ezért hiánypótló munka a kiadvány.

A szerzók elemzésük során közelebb hozzák a pszichológiát és a neveléstudományt is, ez nem véletlen, hiszen az 1980-as évektól kezdődó kutatások kapcsán ma már a két területet nem lehet elválasztani egymástól. (Jackson, 2011) Bár a mögötte álló érvrendszer nem túnik kiemelten megalapozottnak a következó oldalakon, de mindenképpen összeszedett. Különösen az a rész válik nagyon fontossá ebben a fejezetben, amelyben a szerzók a médiát, mint a szocializáció kontextusát határozzák meg. További kulcspont hogy a szerzók a kommunikációtudományt is aktívan bevonják az értelmezésbe a használat és igénykielégítés modell figyelembevételével. Ez a harmadik kognitív modell a média megértésével kapcsolatban, és az egyik legjelentôsebb állomása a hatáskutatások csoportosításának (Robinson és Levy, 1989), ez helyezte önálló alapra a médiáról való gondolkodást, és egyúttal

${ }^{1}$ Kaveri Subrahmanyam - David Smahel (2011): Digital Youth. Springer, New York 
gyökeresen befolyásolja a médiapedagógiát, valamint az azzal kapcsolatos kutatási-oktatási feladatokat.

Áttérve a harmadik fejezetre, a szexualitás témakörében mélyedtek el a szerzók. Dicséretes, hogy ezt a nem könnyen megközelíthetố témát is felvállalták, amelyet sok más kiadványból eddig hiányolhattunk. A szöveg közben hivatkozott gazdag szakirodalom azt mutatja, hogy a téma tudományos kutatása igenis létezik, ráadásul hosszú idó óta releváns. A három kulcsszó a téma körül az elérhetôség, megfizethetôség, és anonimitás - ahogy a tartalomból kiderül. Ez lenne az egyik legégetóbb problémakör a fejezetben, érdemes lett volna egy kicsit több terjedelmet szánni neki, illetve jobban körüljárni a gyerekek egészséges fejlődésére vonatkozó aggályokat. Abban teljesen egyet lehet érteni, hogy a fiatalok a nemi érésró́l vagy viselkedésról szóló információikat a netról szerzik meg, illetve ahhoz igazítják. Az általános kérdés azonban a világháló megbízhatóságáról újra felmerül, és ehhez elengedhetetlen az oktatás részévé tenni a fejezet témakörét. Ezt az utóbbi gondolatot talán hangsúlyosabbá tehették volna az írók, de a fejezet nyújtotta információk így is nagyon informatívak, jól használhatóak.

A következố rész a virtuális identitást tárgyalja. Nagyon elgondolkodtató az utóbbi fogalom négy szerepének a meghatározása az internet esetében. Ezek alapján a tinédzserek egy része nem szereti a maga identitását és ezért alkot új személyiséget, a második esetben bizonytalan és próbál magának egy megfelelố iránymutatást találni. A harmadik lehetôség szerint csak idốnként próbál meg más bơrébe bújni, más tulajdonságokkal felruházni magát, azért, hogy élményekkel legyen gazdagabb. Végül teljesen belemerülhet egy kreált világba, ahol független lehet mindentól, és jól érzi magát. Ezek az állomások persze egymásra is épülnek bizonyos mértékben, és jól elkülönülnek nemenként. Elkülönül a virtuális- és online identitás fogalma, és innen már egyenes út vezet az avatar kutatásokig (Illés et al., 2014). Ez utóbbi persze lehet pozitív kontextusú is, mint ahogy azt a magyar kutatások is mutatják. Az életkor/nem/lakhely (a/s/l, vagyis age/sex/location) meghatározás összevetve egy, a hálón megjelenố becenévvel máris elég néha a fiataloknak hogy hiteles információforrásként kezeljék a másikat. Az összefüggés az on-line identitás és viselkedés között is van: a megkérdezettek csaknem fele azt válaszolta a kutatói kérdésre, hogy a szülei nem nagyon tudják, mit csinál a világhálón. Ötödük egyértelmúen bevallotta, hogy az interneten más személyiséget tükröz a profilja mint a valóságos „,arca”. A könyv gondolatmenete itt egészen kiváló és nagyon jó áttekintést ad a problémakörról, a kutatási kérdések lényegbe vágóak és az internet és a fiatalok látens kapcsolatára világítanak rá. A szakkifejezések súlya és aránya nem zavaró, a hozzájuk fúzött magyarázatok pedig kellóen világosak.

Az ötödik fejezet is tartogat néhány újdonságot, amit hazai kutatásokban nem szoktunk gyakran látni. Az intimitás és a társas kapcsolatok közötti összefüggések akár a csoportkohézió szempontjából is fontos lehet, vagy a társas hálózatok felépítése és szerveződése témakörben is jelenthetnének új kutatási alapokat. A fiúk és lányok itt is jelentôsen eltérố szereplói a digitális világnak: míg a lányok kapcsolatot tartanak és „traccsolnak”, addig a fiók flörtölésre használják többek között a netet. Hasonlóan érdekes az a része a fejezetnek, ahol a baráti kapcsolatra fordított idốt hasonlítják össze: on-line vagy élóben? Befolyásolja-e ez a barátságot? A válaszadók csak pár százaléka mondta azt, hogy a barátokkal való személyes találkozást és a kapcsolatot a világháló kedvezótlenül befolyásolta. A Pew Internet \& American Life Project keretében megkérdezett tizenéves fiatalok 91\% -a vá- 
laszolt úgy, hogy az internethasználatának fó célja a kapcsolattartás. Az viszont nem túnik reálisnak, hogy egy személy több mint ezer „baráttal” rendelkezzen: a kutatók szerint 793 online haver maximum 176 igazinak felel meg a statisztikai számítások alapján. Ijesztố az a felmérés, amely szerint a tinik $32 \%$ lépett kapcsolatba idegenekkel az internet segítségével, és $21 \%$ közülük úgy, hogy nincs is valósként értékelhetô információja az adott személyról. Bár a bibliográfiában megtalálható a teljes projekt szakmai lebonyolításának módszertana, annak kidolgozottsága miatt érdemes lett volna részletesebben is ismertetni a könyv hasábjain is. A kimutatások és számok világa nem minden esetben a barátja - fóként az elméleti kutatóknak - de jelen helyen és összefüggésben jelentősen hozzájárulhat ahhoz, hogy a világháló veszélyességét mennyiségekkel is alátámasszák a szerzók, és ezzel túllépjenek az elméleti gondolkodás keretein.

Ezt a megközelítést követi a szerelmi kapcsolatok alakulása az internet segítségével, amelyból szintén kiderül, hogy a webhasználók kissé naivak. Összességében az egyik legérdekfeszítóbb fejezet az ötödik, a maga egyedülálló felméréseivel, a laikus érdeklődóknek is izgalmas olvasmányt kínál.

A hatodik fejezet morális és etikai kérdésekkel foglakozik. Ez a témakör általános megállapításokat tartalmaz, de nagy értéke hogy sok kutatást hoz példának. Sorra veszi a tinik on-line „búneit”, mint plagizálás, hackelés, megtévesztés, a privát szféra problémái, illegális letöltések - és ezekról egy nagyon logikus, rendezett összefoglalást ad. Itt kapott helyet a fiatalok és társadalmi mozgalmak kapcsolata, de ez a rövid rész viszonylag kevés újdonságot nyújt.

A következő fejezetben a jóllét és internet közötti összefüggést térképezik fel a szerzók, és ez nézốpont szintén sok újdonságot nyújthat a hazai olvasóközönségnek. A világháló elốtt eltöltött idő, vagy annak beosztása kihat a fejlődó szervezettel rendelkezố fiatalok alvási szokásaira, de éppen úgy befolyásolja az olvasási hajlandóságukat vagy ingerküszöbüket, illetve magában hordozza a mozgás iránti igényszintjük változását. Az elhízásra való hajlam vagy éppen elhízottság kockázata már a médiába is gyakori téma, de ha valaki igazán megdöbbentố számokat akar olvasni egy teljesen hiteles szakkönyvból, ezt a fejezetet többször is át fogja lapozni.

Hasonló a helyzet a nyolcadik fejezettel is, amelyból kiderül, hogy a fiatalok egészségtudatos viselkedése gyakran kimerül abban, hogy on-line keresnek információkat az egészségról, vagy betegségról. A The World Internet Project-ból származó adatok megbízhatóak: ez a legnagyobb szabású nemzetközi összehasonlító vizsgálat, amelyben Magyarország 2001 óta vesz részt. A longitudinális monitoring jellegú vizsgálat 2007-es adatai szerepelnek a könyvben, ebból derül ki hogy a Magyarországon éló 12-18 év közöttiek 59\%-a állítólag ezt soha nem tallóznak az egészségról szóló információk között, de 9\%-uk minden nap indít ilyen jellegú keresést. Ez a számadat csak abban a kontextusban lesz hihetô, amelyben a táblázat mutatja: hasonló arányú a helyzet Kanadában, Kínában és ÚjZélandon egyaránt. Jellemzóen a terhesség, AIDS és ehhez hasonló szavak kerülnek a keresóbe. Ez a fejezetrész szintén hiánypótló eredetú lehet a hazai szakirodalmi palettán, bár egy kicsit lehetett volna még részletesebb a leírás. Ebból a részból - kivételesen - hiányzik egy táblázat, amely vizuálisan is jól ábrázolta volna a fiatalok információkeresési szokásait. Az internetfüggốségról és normális viselkedésról alkotott józan észbeli meglátásokat kiválóan kiegészíti és körülhatárolja a szerzôpáros. Némi jóindulattal akár kötelezó olvasmányként is lehetne ajánlani szülóknek, gyakorló tanároknak egyaránt. Nem csak a 
közösségi portálok vagy az internetes játékok jól ismert oldalai felól közelítik meg a témát az írók, ezért nagyon alapos képet kaphat az olvasó. Megpróbálják feltárni a felhasználóközpontú elemzést is, vagyis a motivációból és használatból vezetik le a lehetséges hatást. Ennek az előnye hogy közelebb visz az élményközpontú megközelítéshez, és nem a tapasztalt jelenségekból deduktívan vezetik le a következtetéseiket. Szerencsére egy a könyvben is szereplő kimutatásból kiderül, hogy a szerencsejáték és fogadás még gyerekcipóben jár a fiatalok körében, bár kétségtelen tény, hogy komoly veszélyeket jelenthet az így kialakuló függóség. A szerencsejáték-függóség hozzávetólegesen húsz éves történetének alapos és releváns áttekintése után, néhány kezelésról is többet tudhat meg az érdeklődoo, de ez az áttekintés viszont túlzottan pszichológiai „ízú”.

A tízedik fejezet már a web komoly „sötét oldala”, az erószak körül forog. A médiaerôszak kezdeti és igen aktív kutató igencsak csodálkoznának, hogy nem is feltétlenül a szórakoztatóipar által létrehozott tartalmak jelentik a legnagyobb kihívást a XXI. században a fiataloknak. Az általános és kötelezố témák után jön a legizgalmasabb, az on-line gyúlölet, vagyis mások cyber-nyilvános megszégyenítése. Kiderül, hogy már több mint tíz éve komoly szakirodalma van a témának, hiába kapta fel a híradások némelyike csak mostanában. A fogalmak és áttekintés alapos, de nem nyújtja azt az izgalmat, amit az elózó fejezetekhez képest várnánk.

A tizenegyedik fejezet eleje általánosságban ír a fiatalok megóvásának néhány szereplójéról, többek között a közigazgatásról, azonban jóval izgalmasabb téma pár oldallal késóbb a szülók „feladata”, természetesen a normatív kontrollon kívül (McQuail, 2003). Sajnos a világ olyan gyorsan változik, hogy az ajánlott technikák (például közös megtekintés) ma már nem múködnének valószínúleg, és sajnos a hivatkozott irodalom is viszonylagosan régi: 5-7 éves.

A könyv utolsó része a jövố lépései felé tereli az olvasót, és felállítja még egyszer fejezetenkénti bontásban az összefüggéseket, kiemelten fontos csomópontokat.

A névmutató nagyon alapos, és mindenre kiterjed, ezért a könyv egyszerú böngészésre is alkalmas, de mindenképen érdemes belemélyedni. Bár tudományos igényú múként aposztrofálható, minden szinte csak kicsit is érdeklődő talál benne számos érdekességet. Feltehetốen még azok is, akikról szól...

\section{Irodalom}

Illés A., Bényei J., Pataky G., Ruttkay Zs., Schmidt A. (2014): Gyermekek avatar választási tendenciái. In: Kultúra él közösség, 2014/3. 95-102 p.

Jackson, Y. (2011): The Pedagogy of Confidence. Columbia University, New York and London.

McQuail, D. (2003): A tömegkommunikáció elmélete. Osiris, Budapest,

Robinson, J. P. és Levy, M. (1986, szerk.): The Main Source: Learning from Television News. CA: Sage, Beverly Hills. 